\title{
Effect of the Emotional Freedom Technique on Emotional Stability in Adolescent Prisoners
}

\author{
Salis Miftahul Khoeriyah*, Dina Putri Utami Lubis, Istichomah \\ Nursing Programed, Institute of Health Science Yogyakarta, Indonesia \\ E-mail*:miftakhul.khoery@gmail.com
}

\begin{abstract}
Introduction: The prevalence of children in Indonesian prisons in 2015 was as many as 2,207 children. The impact of detention on children can cause a psychological decline such as anger, anxiety, sadness, fear, disappointment, and other feelings that can cause changes in their emotional stability. The Therapy Emotional Freedom Technique (EFT) is one of the complementary therapies that can be administered to improve the emotional stability of adolescent prisoners. This study set out to determine the effect of emotional stability EFT against child prisoners in LPKA Class II Yogyakarta. Methods: This study design used a pre-experimental approach in a non-equivalent control group design. The researcher used purposive sampling to gain a sample of 32 respondents consisting of 16 respondents in the intervention group and 16 respondents in the control group. The research instrument used was Questionnaire Emotional Stability. The data analysis used an Independent t-test. Results: The results showed that there were differences in the average emotional stability between the intervention group and the control group with $p=0.000$ ( $p<0.05)$. Conclusions: EFT therapy is highly recommended as one of the nursing interventions to increase emotional stability in adolescents.
\end{abstract}

Keywords: Emotional Freedom Technique, emotional stability, juvenile prisoners

\section{INTRODUCTION}

Adolescents are a valuable asset of the nation in realizing the progress of the country as a whole. It is said that because adolescents are the younger generation, that are the successors of the nation's ideals that are proven to be able to make changes (change agent) and solve problems in a more creative, simple, and concise manner (Subiyakto, 2012). The involvement of adolescents in development is contained in the Regulation of the Minister of Women's Empowerment and Child Protection No. 03 of 2011 in Article 1, paragraph 2, which contains the policy on the participation of children in development.

Attention to adolescents has been attempted by the government, but the crime rates in adolescents is still high. Teenagers not only become the victims of criminal behavior, but they become adolescents who are the perpetrators of crime. The National Center for Juvenile Justice (NCJJ) 2014 said that law enforcement agencies in the United States caught 1.3 million adolescents under the age of 18 over the 2012 span. The majority of juvenile arrests were for theft (224,200 cases). In the arrest, as many as 4 out of $10(42 \%)$ arrests included women, $29 \%$ involved 15 year-olds, and $61 \%$ of them were white teenagers (Sickmund, 2014).

In Indonesia, the prevalence of the complaints focused on child crimes in 2014 according to the Indonesian Child Protection Commission (KPAI) (2016) found that there were 445 complaints with 67 cases where child were the perpetrators of violence. This increased in 2015 to 79 cases. Based on the data from UNICEF (2015) in 2014, there were 3,488 children in Indonesian penitentiary institutions and this decreased in March 2015 to 2,207 children. The decline was due to the diversions (coaching of the child).

The cause of teenagers being in prisons is caused by various criminal cases. Based on the Child Trends Data Bank (2015) study on juvenile inmates in the United States, 
they found that about 44 adolescents out of the 100,000 adolescent population experienced detention because they were the perpetrators of rape. Meanwhile, Cahyaningtyas (2013), in his research in Prison Class II Blitar, found that the most dominant crime was rape at $41.4 \%$ followed by theft and murder at $20.7 \%$. The rest was evenly spread over maltreatment, drugs, and extortion.

Negative emotions should be anticipated or even prevented so then the children do not feel depressed, thus resulting in a greater psychological impact from mental development disorders. The psychological impact of detention on the convicted child is based on a report from the American Academy of Pediatrics (2014), indicating that the prevalence of psychiatric disorders among adolescents in the penitentiary was high at an average of $16.5 \%$ (range: $6.2 \%$ - $41.3 \%$ ). The research conducted by Rahmawati et.al (2015) also showed that the adolescent depression was often due to the high detention rate. The results showed that out of the 46 juvenile inmates, as many as 28 people $(60.9 \%)$ experienced depression. Adolescents should be trained early on to have good emotional stability. Emotional stability aims to improve the quality of one's life such as self-acceptance, selfconfidence, achievement and self-concept.

There are various ways to improve emotional stability through appropriate emotional management. Many of the emotional management methods that have been developed and that are effective for controlling emotions in prisoners use the Emotional Freedom Technique (EFT). EFT is one of the complementary forms of therapy developed by Gary Craig in the mid-1990s, as one variant of a new science of psychology called Energy Psychology. This is in which the technique combines psychotherapy and acupuncture techniques with tapping methods on parts of the body to improve the body's energy systems that affect the state of mind, emotions and behavior (Zainuddin, 2008).

The effectiveness of EFT has been demonstrated in the research by Shari et al (2014). The study explained that as criteria. The inclusion criteria of the intervention and control group were that many as 30 teenagers who underwent the procedure of Percutaneous Coronary Intervention (PCI) suffered from anxiety. Out of the 30 teenagers, 15 adolescents were given EFT intervention for 15 minutes, while the rest were not given any treatment. The result was a significant difference in the decrease in the intensity of anxiety after EFT was administered compared to those not being given any treatment.

Based on the preliminary study in June 2017 at the Institution of Special Guidance of Children Class II in Yogyakarta, the recorded number of detainee counted 33 children. All children were of the male gender. The Standard of Child Protective Capacity exceeds capacity. When the researcher interviewed three prisoners, all of them said that they often felt sad and suddenly angry with themselves. They felt regret for the crimes that they had done, which makes them feel afraid that they will lose their future.

\section{MATERIALS AND METHODS}

This research used a quantitative research approach using a preexperimental design. The approach (type) of the research used was a nonequivalent control group design (control group and experimental group). This study was conducted by grouping the sample members into the experimental and control groups (Notoatmodjo, 2015). The treatment group in this research were the respondents who had been using EFT to regulate emotional stability and and the control group were the respondents who did not do an intervention. Both groups were pretested and post-tested. The pre Test was done before the EFT and the post-test was done after the EFT. EFT was also administered to the control group one day later after the post- test.

Sampling in this research was done through the purposive sampling technique, thus account for all juvenile inmates in LPKA Class II in Yogyakarta. The characteristics of the study sample included the inclusion and exclusion

they were willing to be a research respondent, that they were communicative and co-operative, that they had full 
awareness, and that they were of the male sex.

The exclusion criteria included inmates who were mentally ill, and the prisoners who were receiving other pharmacological and non-pharmacological therapies to decrease their emotional instability. Next. the age of the respondent and the duration of their sentence was noted. The data collection tool used to measure emotional stability in this research was a questionnaire.

This research was conducted at Lembaga Pembinaan Khusus Anak (LPKA) Class II in Yogyakarta. The research obtained ethical approval from the chairman of the Ethics Committee at the Research Institute and Community Service department of the The Institute of Health Science in Yogyakarta referring to No: KE/ STIKESYO /16 /EC. In addition, this research has also been approved by KEMENHUMHAM D.I. Yogyakarta.

\section{RESULTS}

The results of this study provided data on the characteristics of the respondents including age, the duration of their sentence, the univariate analysis results, and the influence of the Emotional Freedom Technique (EFT) on emotional stability, age and the duration of sentence with their emotional stability presented based on the results of bivariate analysis.

Based on the analysis results, we obtained that the average length of the term of the adolescent's stay was 4.72 months, with a median 4 months $(95 \% \mathrm{CI}$ : 3.82 - 5.62) with a standard deviation of 2.495. The lowest sentence was 1 month and the duration of the longest sentence was 11 months. It can be concluded that $95 \%$ believed that the average duration of a juvenile convict's sentence in LPKA Class II in Yogyakarta in July 2017 was between 3.82 months and 5.62 months.

Based on Table 2 above, the results show that the p-value of the adolescent's age associated with emotional stability was $\mathrm{p}=0,139$. This equals $\mathrm{p}>$ 0.05 , so it can be concluded that there is no relationship between the age of the adolescents with their teen emotional stability score. Furthermore, the p-value of the duration of the sentence is related to emotional stability, which is $\mathrm{p}=0.861$. The conclusion is that there is no correlation between the duration of the juvenile's sentence and the emotional stability score of the juvenile inmates ( $p>0.05)$.

The results of the research on the average score of the adolescent's emotional stability in LPKA Class II in Yogyakarta before getting EFT therapy was 64.06 with a standard deviation of 10.129. After the adolescents got EFT therapy, the result was 82.13 with a standard deviation of 12.010. Based on the results, there is a difference of value of the average score of emotional stability score, which was 18.7. The statistic test result was $\mathrm{p}$-value $=0,000$. This means that at alpha $5 \%$ with a $95 \%$ confidence degree, there was a significant difference between the average emotional stability in LPKA Class II in Yogyakarta before and after getting EFT therapy ( $p<0.05)$.

Table 4 explains that the results of the research concerning the average emotional stability score of the control group in LPKA Class II in Yogyakarta in the pretest was 65,00 with a standard deviation of 8.702. The post-test of the control group was 65.63 with a standard deviation of 5.898. Based on these results, there is an the average value in the emotional stability score of 0.63 and the statistical test results obtained a p-value $=$ 0.751 . This means that at alpha $5 \%$ with a $95 \%$ confidence level, there is no significant difference between the mean of emotional stability in LPKA Class II i n Yogyakarta before and after getting EFT therapy $(p>0.05)$.

Based on Table 4.5, the results showed that the average score of emotional stability in LPKA Class II in Yogyakarta in the post-test of the intervention group was 82.13 with a standard deviation of 9.382. In the control group, this was 66.19 with a standard deviation of 12.010. This indicates that there is difference in the value of the mean score of emotional stability between the intervention group and control group equal to 15.94. The statistical test results obtained a $\mathrm{p}$-value $=0.000$. It can thus be concluded that there is a significant difference in the average of emotional stability in LPKA Class II in Yogyakarta, which shows that there is an influence from 
Jurnal INJEC Vol. 3 No. 1 Juni 2018: 15-21

EFT on the emotional stability of juvenile inmates in LPKA Class II Yogyakarta $(\mathrm{p}<0.05)$.

The most common age was middle age (Anjaswarni, 2014). Age is one of the most important indicators when determining the maturity level of a person.

\section{DISCUSSION}

Table 1. Distribution of the respondents based on age and duration of adolescence in LPKA Class II Yogyakarta on July 2017(n=32)

\begin{tabular}{lccccc}
\hline Variable & Mean & Median & S.D & $\begin{array}{c}\text { Minimum- } \\
\text { maximum }\end{array}$ & 95\% CI \\
\hline Age & 16.03 & 16 & 1.177 & $14-18$ & $15.61-16.46$ \\
Duration of adolescence & 4.72 & 4 & 2.495 & $1-11$ & $3.82-5.62$
\end{tabular}

Source: Analysis Data Primer (2017)

Table 2. Analysis of the relational characteristics of the adolescent prisoners: age and length of time in detention with emotional stability in LPKA class II Yogyakarta on July $2017(n=32)$

\begin{tabular}{lll}
\hline Characteristics of Adolescent & $\mathrm{R}$ & p value \\
\hline Age & 1.000 & 0.139 \\
Length of time in detention & 1.000 & 0.861 \\
\hline
\end{tabular}

Source: Analysis Data Primer (2017)

Table 3. Average difference of emotional stability scores of adolescent prisoners in LPKA class II Yogyakarta before and after EFT therapy on July $2017(\mathbf{n}=16)$

\begin{tabular}{llllll}
\hline Emotional Stability Scores & Mean & SD & SE & p value & $\mathrm{N}$ \\
\hline Pre-Test & 64.06 & 10.129 & 2.532 & 0.000 & 16 \\
Post-Test & 82.13 & 12.010 & 3.003 & & 16 \\
\hline
\end{tabular}

Source: Analysis Data Primer (2017)

Table 4. Differences in the emotional stability scores of the adolescents at LPKA class II Yogyakarta in control group on July $2017(n=16)$

\begin{tabular}{llllll}
\hline Emotional Stability Scores & Mean & SD & SE & $p$ Value & N \\
\hline Pre-Test & 65.00 & 8.702 & 2.176 & 0.751 & 16 \\
Post-Test & 65.63 & 5.898 & 1.474 & & 16 \\
\hline Source: Analysis
\end{tabular}

Source: Analysis Data Primer (2017)

Table 5. Average differences in the emotional stability scores of the adolescent prisoners in LPKA class II Yogyakarta between the EFT intervention group and control group on July $2017(\mathrm{~N}=32)$

\begin{tabular}{cccccc}
\hline Emotional Stability Scores & Mean & SD & SE & p Value & $\mathrm{N}$ \\
\hline Control & 66,19 & 9,382 & 2,346 & 0,000 & 16 \\
EFT & 82,13 & 12,010 & 3,003 & & 16 \\
\hline
\end{tabular}


Maturity here is not only physically, but also psychologically. The older a person's age, the more mature their thoughts, behavior, and mastery of their emotions will be (Hurlock, 2012).

Living in a penitentiary and away from a known person will make their psychological condition decline, especially for adolescents at the time when adolescents are in transition. According to Sarwono (2015), teenagers characterize the transition period by searching for their identity, and the process of socialization and the support of their family and peers is needed. Therefore, the process of the socialization approach is directed by the prison officers and the juvenile's supportive peers are needed. Therefore, any emotional pressure can be well controlled. Imprisonment is a life event that can cause stress, putting the individual at risk of depression (Reeder, Martin \& Grifin, 2007 in Hardiani, 2012).

Life inside LPKA is isolated from the outside environment, away from loved ones. This will cause psychological shock for teenagers, in addition to feelings of sadness, anxiety, anger and fear. This makes a juvenile prisoner vulnerable to mental health problems, especially those associated with the problem of emotional stability.

Most teenagers in jail have mental health problems such as depression, and have made suicide attempts. This problem is compounded by the adverse conditions experienced during imprisonment, where the adolescents have to adapt to the prison environment. During detention, adolescents experience isolation, boredom, intimidation, and stress $(\mathrm{Ng}$ et al., 2011). The adolescents should be supported by good moral reasoning (Desmita, 2007), self-study and socially responsible behavior (Haviguhurst, 1976) in Sobur, 2015). Teenagers who are in LPKA will experience the same situation, facilities and treatment as adults. Teenagers will feel depressed, and their independence is limited, away from their parents, family and closest friends, which means that the developmental tasks that teenagers should complete will be hampered. Child developmental tasks going incompleted results in unhappiness in adolescents, causing community rejection, and difficulty when trying to complete the task of developing into the next Stage of life (Havighurst, 1961 in Yusuf, 2015).

The difficult conditions experienced by juvenile inmates causes the teenagers to feel isolated, hollow, anxious and indecisive. Feelings of sadness, worry, fear and disappointment can make a prisoner difficult when it comes to maintaining their emotional stability. In addition, activities that are routinely done every day will make teenagers feel bored, and they will tend not do their hobbies outdoors. The emotions of young adolescents entering LPKA tended to be due to the inability of the adolescents to adapt to the new environment, while the long-time adolescents in LPKA felt anxiety and fear in the face of their freedom. This causes most of them to feel the same emotional intensity though their length of time in detention was different. This study is in line with Helm's research (2014) and that of Mares (2016), which showed that there is no correlation between detention length and mental health in juveniles.

This research method refers to Zainudin (2008), who used Borrowing Benefits in the subject of their research. Furthermore, research on the effectiveness of EFT using the Borrowing Benefits method was done by Church, et al (2012) on 9 students who suffered from severe depression with an average score of 23.44. The treatment group received four EFT sessions in groups for a period of 3 consecutive weeks. Each session lasted 90 minutes. After 3 weeks, the average depression score decreased to 6.08 . This shows that the effect of EFT using the Borrowing Benefits method is very effective against depression. The effect of EFT has also been proven by Suh (2015) by examining the symptoms of anxiety and anger in adolescents in as many as 27 teenagers who have Hwabyung syndrome (HB) in Korea. Suh identified their starting capacity to reduce anxiety, anger, and emotional outbursts. Remeen then taught EFT for four weeks using the 
Borrowing Benefits method. The result is that the EFT group experienced a significant decrease in the HB scale with a $p$-value $<0.05$. The results of this study are also supported by the research conducted by Hartini (2014) using EFT therapy in groups to reduce the degree of depression recorded in female prisoners Class II - A Class Jl. EFT was conducted through 5 meetings with each meeting involving as many as 5 sessions within one hour on female prisoners. As many as 18 respondents who were given the EFT intervention experienced a decrease in their depression by $60.68 \%$. This shows that EFT using the Borrowing Benefit method has a very strong effect when it comes to overcoming emotional disturbance. It is short, cheap and efficient.

\section{CONCLUSION}

The average age of the respondents was 16.03 years with the highest duration of their stay being 4.72 months. There is no relationship between the respondent's characteristic: i.e. age and the duration of their sentence with the emotional stability of their children with a $p$ value $>0.05$. There was a significant mean difference between the emotional stability score before and after being given EFT with a $\mathrm{p}$-value $=0.026$. There was no significant mean difference in the stability score of the pre-and post-child emotions that were not treated with a p-value of 0.751. There was a significant mean difference in emotional stability between the groups given EFT and the control group with a $\mathrm{p}=0.000$. EFT therapy can be applied as part of the nursing care process to improve the physiological and psychological problems encountered by children, so there is a need for policies from the head of the child-specific coaching agency to pursue EFT training for all LPKA officers.

\section{REFERENCES}

American Academy of Pediatrics. (2011). Health care for youth in the juvenile justice system. Pediatrics Journal.DOI:10.1542/peds.2011- 1757 Anjaswarni,T.(2014).Juvenile delinquency kenakalan remaja:teori,hasil penelitian dan aplikasi asuhan keperawatan.Sidoarjo:Zifatama Publisher

Cahyaningtyas, A. A .(2013). Faktor penyebab anak bermasalah dengan hukum studi kasus di lembaga pemasyarakatan kelas IIa anak blitar. Jurnal Psychology 2013. Vol.4, No.8, 645-654 Published in

SciRes (http://dx.doi.org/10.4236/psych.2 013.48092

Church,D.,\&Brooks,A.(2013). The effect of eft (emotional freedom techniques) on psychological symptoms in addiction treatment: A pilot study.Journal of Scientific Research \& Reports 2(1): 315-323, 2013; Article no.

JSRR.2013.021.Sciencedomain international www.sciencedomain.org

Desmita.(2007).Psikologi perkembangan peserta didik.Bandung: PT Rosdakarya

Hardiani, C.A.(2012). Kecemasan dalam menghadapi masa bebas pada narapidana anak di lembaga pemasyarakatan anak kutoarjo. dari http://eprints.uny.ac.id/9709/1/BA B\%201\%20-07104244004.pdf, diperoleh pada tanggal 14 Maret 2016 Hartini, R.S.(2014).pengaruh terapi kombinasi emotional freedom technique dan terapi relaksasi terhadap derajat depresi narapidana wanita di lembaga pemasyarakatan klas ii a yogyakarta,tesis. Fakultas Kedokteran Universitas Gadjah Mada.

Helm, P.V.D., Beunk,L, Stams,G.J \& aan, P.V.(2014). The Relationship Between Detention Length, Living Group Climate, Coping, and Treatment Motivation Among Juvenile Delinquents in a Youth Correctional Facility. The Prison Journal 2014, Vol. 94(2) 260-275. DOI: 10.1177/0032885514524884.Sage Publication

Hurlock,E.B.(2012).Psikologiperkembangan suatu pendekatan sepanjang rentang kehidupan edisi kelima.Jakarta:Erlangga

Maharis,A.(2015). Pembinaan anak didik pemasyarakatan di lembaga pemasyarakatan anak kutoarjo,tesis.Semarang: 
Effect Of Emotional Freedom Technique ... (Salis, et.all)

Universitas Negeri Semarang

Mares,S.(2016). The Mental Health of

Children and Parents Detained on

Christmas Island Secondary

Analysis of an Australian Human

Rights Commission Data

Set.Health and Human Rights Journal.

$\mathrm{Ng}$, I,et al. (2011). Incarcerating juveniles in adult prisons as a factor in depression. Criminal Behavior and Mental Health, 21(1), 21-34. http://dx.doi.org/10.1002/cbm.783

Notoatmodjo, S (2015). Metodologi Penelitian Kesehatan. Jakarta: PT.Rineka Cipta

Rahmawati,L.dkk.(2015).Hubungan dukungan keluarga dengan tingkat depresi remaja di lembaga pemasyarakatan. Program Studi Ilmu Keperawatan Universitas Riau

Sarwono, S.W.(2015).Psikologi remaja.Jakarta:Rajawali Perss

Shari,W.W.dkk.(2014).Emotional freedom techniques dan tingkat kecemasan pasien yang akan menjalani percutaneous coronary intervention. PSIK Fakultas Kedokteran

Universitas Sriwijaya, Fakultas Keperawatan Universitas Padjadjaran Volume 2 Nomor 3 Desember 2014
Sickmund,M.,\&Puzzanchera,C.(2014).Juven ile offenders and victims:2014 National Report. Pittsburgh, PA: National Center for Juvenile Justice Sobur,A.(2013).Psikologi umum dalam lintasan sejarah. Bandung:CV Pustaka Setia.

Subiyakto, R.(2012).Membangun kota layak anak: Studi kebijakan publik di era otonomi daerah. SOSIORELIGIA, Vol. 10, No.1, Februari 2012

Suh, J.W.dkk. (2015).Anxiety and anger symptoms in hwabyung patients improved more following 4 weeks of the emotional freedom technique program compared to the progressive muscle relaxation program: A randomized controlled trial. hindawi publishing corporation.evidence-based complementary and alternative medicine.Volume 2015, Article ID 203612, pages.http://dx.doi.org/10.1155/201 $5 / 203612$

Yusuf, S.(2015). Psikologi perkembangan anak dan remaja.Bandung: PT Remaja Rosdakarya

Zainuddin,A.F.(2008).Spiritual emotional freedom technique.Jakarta:Afzan Publishing. 